\title{
THE SUPERSTITION HILLS, CALIFORNIA, EARTHQUAKES OF 24 NOVEMBER 1987
}

\author{
By Harold Magistrale, Lucile Jones, and Hiroo Kanamori
}

\begin{abstract}
The 24 November 1987 Superstition Hills earthquakes occurred on the conjugate northwest-striking right-lateral Superstition Hills fault and a previously unknown northeast-striking left-lateral structure defined by a lineation of hypocenters extending from the Superstition Hills fault to the Brawley seismic zone. Master event locations of the earthquakes using Caltech-USGS seismic network data reveal the following. The first main shock $\left(33^{\circ} 4.9^{\prime} \mathrm{N}, 115^{\circ} 47.7^{\prime}, h=10.6\right.$ $\mathrm{km}, M_{\mathrm{s}}=6.2,0154 \mathrm{GMT}$ ), on the northeast striking structure and its foreshocks co-locate. Events on the northeast structure cluster in space and time, and some aftershocks occur in the Brawley seismic zone. The second main shock $\left(33^{\circ} 0.9^{\prime}\right.$ $\mathrm{N}, 115^{\circ} 50.9^{\prime} \mathrm{W}, h=1.9 \mathrm{~km}, M_{s}=6.6,1315 \mathrm{GMT}$ ), on the Superstition Hills fault, was $12 \mathrm{hr}$ after the first main shock and initiated at shallow depth where the two trends join. Aftershocks of the second main shock lie in a northwest trend between the Superstition Hills and Superstition Mountain faults and have a sharply defined western edge. The extent of the northwest-trend aftershocks is not coincident with surface rupture on the Superstition Hills fault. In general, the earthquakes in the northeast trend are deep and the earthquakes in the northwest trend are shallow. We compare the earthquake distribution to the distribution of crystalline basement rocks defined from a refraction study of Fuis et al. (1982). The earthquake locations and extent of aftershock activity appear to be controlled by the presence of crystalline basement rocks.
\end{abstract}

\section{INTRODUCTION}

The 24 November 1987, Superstition Hills earthquakes occurred in the western Imperial Valley in southern California (Fig. 1). The earthquakes took place on a conjugate fault system consisting of the northwest-striking Superstition Hills fault and a previously unknown northeast-striking structure defined by surface rupture and a lineation of hypocenters. The earthquake sequence consists of foreshocks, the $M_{s}=6.2$ first main shock, and aftershocks on the northeast structure followed by the $M_{s}=6.6$ second main shock and aftershocks on the Superstition Hills fault. Here we present the results of master event relocations of the earthquake sequence and relate the earthquake locations to the distribution of basement rocks in the western Imperial Valley.

The Superstition Hills fault is a member of the San Jacinto fault zone (Sharp, 1972). The fault displayed minor surface rupture from a $M_{L}=5.6$ earthquake in 1951 (Allen et al., 1965) and right-lateral triggered slip occurred following the 1968 $M_{L}=6.5$ Borrego Mountain earthquake on the Coyote Creek fault (Allen et al., 1972), the $1979 M_{L}=6.6$ Imperial Valley earthquake on the Imperial fault (Fuis, 1982), and the $1981 M_{L}=5$. 6. Westmorland earthquake on a northeast-trending seismic lineament (Sharp et al., 1986). These earthquakes were the largest recent earthquakes in this area (Fig. 1). The second main shock of the November 1987 sequence produced right-lateral surface rupture on the Superstition Hills fault. The extent of this rupture is coincident with that of the 1968 and 1979 triggered slip except at the southern end of the fault where a $4 \mathrm{~km}$ en-echelon fault segment also ruptured in 1987 earthquake (R. V. Sharp, personal comm.). 
Background seismicity from the Caltech catalog (Fig. 2) shows no obvious indication of the northeast-trending structure on which the first main shock took place (compare Fig. 2 and Fig. 3). The first main shock presumably caused the leftlateral surface rupture observed on numerous short faults striking northeast from near the north end of the Superstition Hills fault (R. V. Sharp, personal comm.); these faults, however, were not field checked between the first and second main shocks. The first main shock did not produce surface rupture on the Superstition Hills fault (J. Kahle, personal comm.).

\section{DATA AND METHODS}

The earthquakes were recorded on the Caltech-USGS seismic network in southern California. Routine processing (Given et al, 1986) of events recorded from 24 November to 28 November 1987 produced the arrival times and first motions used here. To constrain the depth of the second main shock, $S$-wave arrival times from a permanent station at Superstition Mountain and the temporary station KNB of the USGS Imperial Valley strong-motion network (Porcella et al., 1987) and a KNB $P$-wave arrival time from a private seismograph network (I. Lutz, personal comm.) are added to the phase file of the second main shock. The events are sorted by time into two groups, those events that occurred before the second main shock and lie within the northeast trend, and those events that occurred after the second main

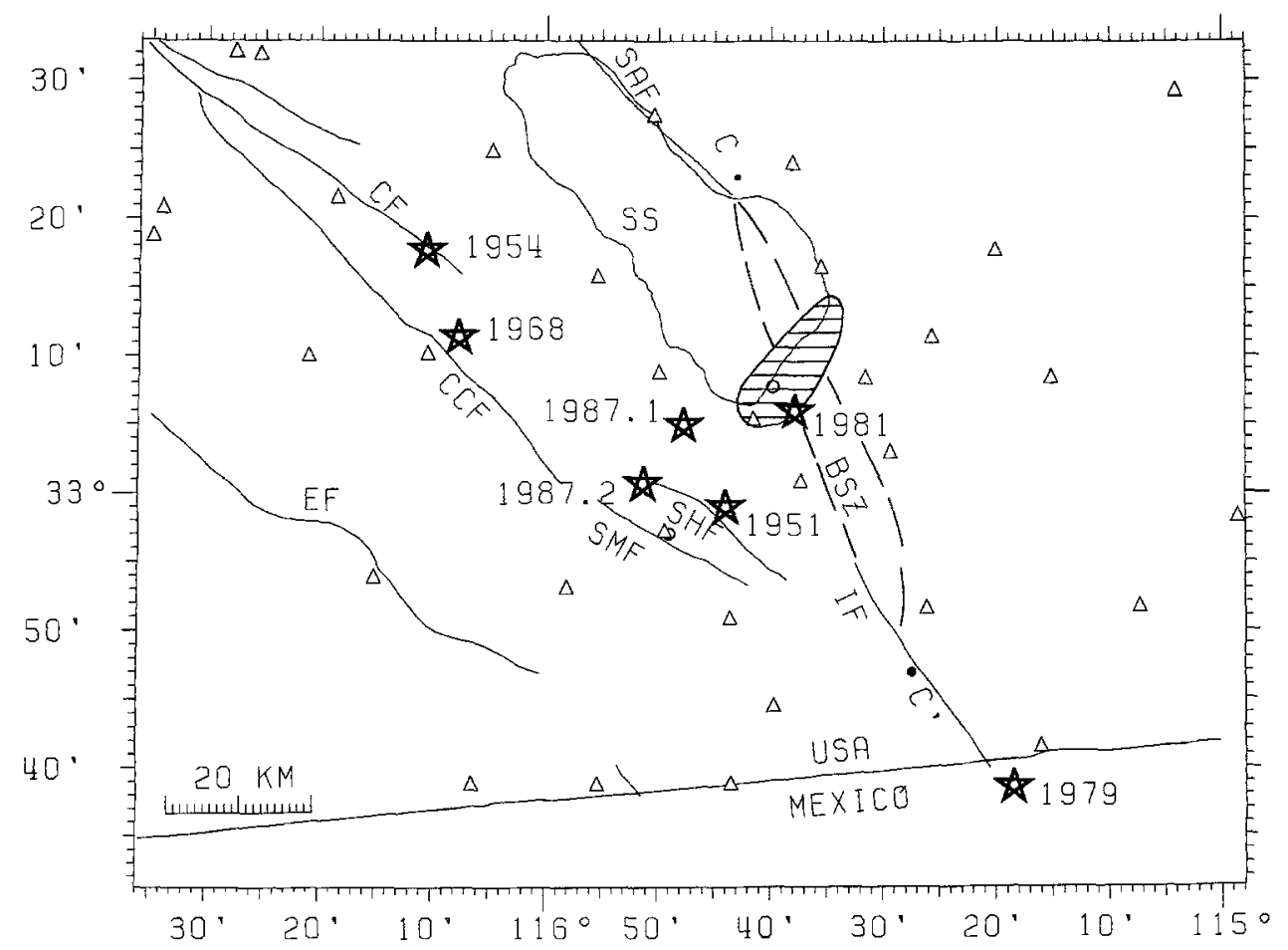

FrG. 1. Reference map of the study area showing major faults and other features. Triangles are seismograph stations. Circles are strong-motion instruments mentioned in text. Stars indicate earthquakes mentioned in text, labeled with year of occurrence. 1987.1 and 1987.2 indicate the first and second main shocks, respectively, of the 24 November 1987 sequence. Area of horizontal stripes is the Salton-Westmorland geothermal area. Area within dashed lines is the Brawley seismic zone. CC' is location of cross section shown in Figure 9 . Abbreviations: SS. Salton Sea; SAF, San Andreas fault; CF, Clark fault; CCF, Coyote Creek fault; EF, Elsinore fault; SHF, Superstition Hills fault; SMF, Superstition Mountain fault; IF, Imperial fault, BSZ, Brawley seismic zone. 
CALTECH CATALOG 1980-1986

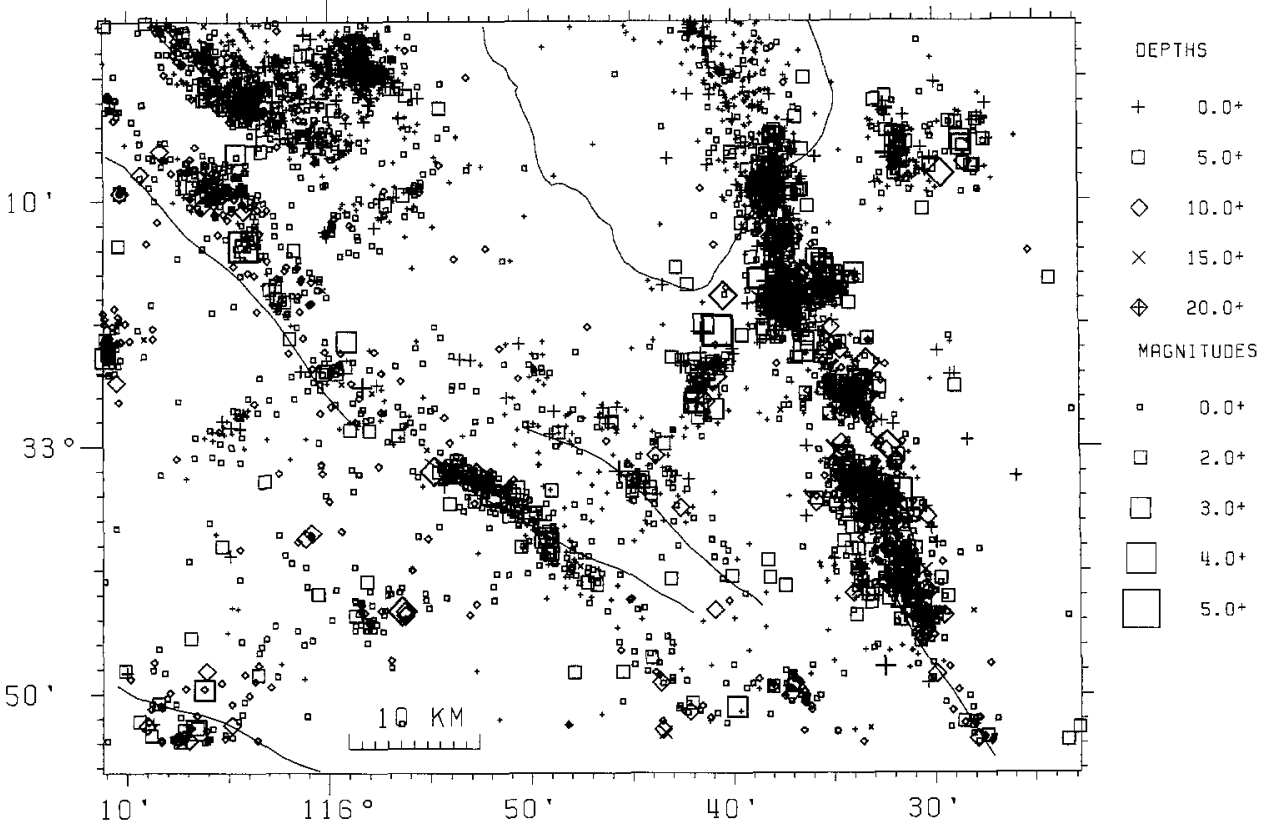

FIG. 2. All earthquake locations from the Caltech catalog from 1980 to 1986 in the Imperial Valley region. The Westmorland sequence, mentioned in the text, is the alignment of events occurred at $33^{\circ} 2^{\prime}$ $\mathrm{N}, 115^{\circ} 41^{\prime} \mathrm{W}$, between the Superstition Hills fault and the Brawley seismic zone.

\section{SUPERSTITIUN HILLS EVENTS}

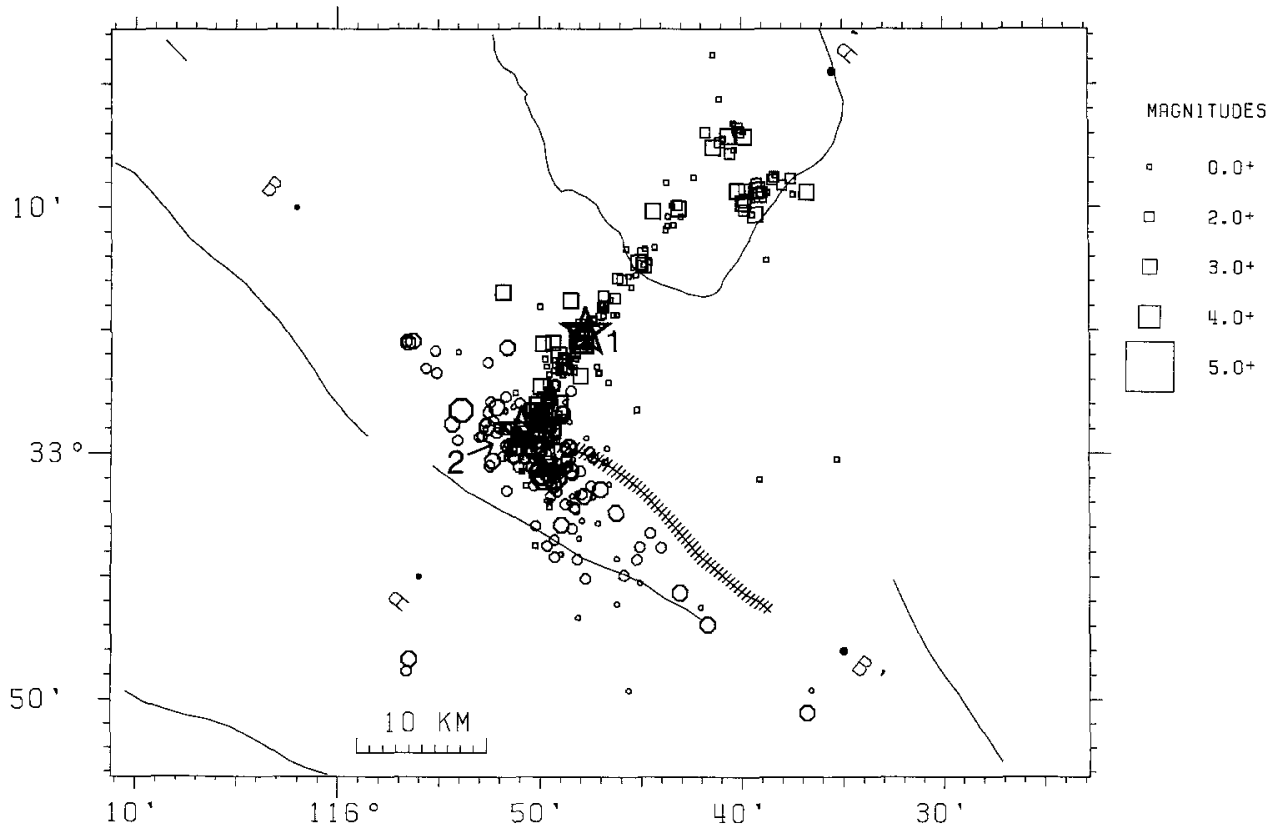

FIG. 3. Events relocated in this study. Main shocks are indicated by stars. The first and second main shocks are labeled with 1 and 2, respectively. Events before the second main shock are shown by squares. Events after the second main shock are shown by octagons. Hachuring shows the approximate extent of surface rupture on the Superstition Hill fault. $\mathrm{AA}^{\prime}$ is location of the cross section shown in Figure 4. $\mathrm{BB}^{\prime}$ is location of cross section shown in Figure 5. 
shock and lie mostly in the northwest trend. Because the velocity structure differs between the western and the central Imperial Valley (Fuis et al., 1982), different master events and velocity models are used in relocating the two groups. For the northeast group, a well-recorded foreshock serves as the master event, and the velocity model (Table 1) of Fuis et al. (1982) (Fig. 22, southeast of shotpoint 13) is used.

The master event for the northwest-trending group is a $\hat{19} \overline{8} \tilde{5}$ earthquake from the Caltech catalog. Two velocity models are used for this group, depending on the azimuth of the seismic recording station from the second main shock. Stations west' of a line through the second main shock epicenter and parallel to the San Jacinto' fault zone use the velocity model of Hamilton (1970) (Table 1), which is appropriate for the thinner sediments and shallower basement of the western Imperial Valley.' Stations east of the line use a velocity model (Table 1) of Fuis et al. (1982) (Fig. 22,' east of shotpoint 1).

The earthquakes are relocated using the program HYPOINVERSE (Klein, 1985), with station delays derived from the master events. In the hypocenter plots below,' only earthquakes with horizontal and vertical location errors of less than $2 \mathrm{~km}$, as' indicated by the HYPOINVERSE parameters ERH and ERZ (Klein, 1985), are" plotted. Of the 653 events processed, 386 meet these criteria.

Focal mechanisms are determined for $29 M_{L} \geqq 3.0$ events that have more than $15^{j}$ first motions by the grid searching program FPFIT (Reasenberg and Oppenheimer,' 1985) after correcting the polarities of reversed seismometers with the information ${ }^{1}$ of Norris et al. (1986). The first motions were picked during routine processing and,' except for the second main shock, not rechecked.

\section{RESULTS}

The relocated earthquakes are plotted in Figure 3. The first main shock (0154:13.7, 24 November 1987 GMT) location is $33^{\circ} 4.9^{\prime} \mathrm{N}, 115^{\circ} 47.7^{\prime} \mathrm{W}$, at a depth of $10.6^{j}$ $\mathrm{km}$. The first main shock, its foreshocks, and its aftershocks define a northeast-" striking structure running from the northern end of the Superstition Hills fault to ${ }^{3}$ the northern end of the Brawley seismic zone defined by Johnson (1979). Many aftershocks occur within the Brawley seismic zone. Southwest of the first main ${ }^{\text {? }}$ shock, the northeast structure bends to a more northerly strike and butts into the northwest trend, near the north end of the Superstition Hills fault.

TABLE 1

\begin{tabular}{|c|c|c|c|c|c|}
\hline \multicolumn{6}{|c|}{ VELOCITY MODELS } \\
\hline \multicolumn{2}{|c|}{ NE } & \multicolumn{2}{|c|}{ NW west } & \multicolumn{2}{|c|}{ NW east } \\
\hline $\begin{array}{c}P \text {-Wave } \\
\text { Velocity } \\
(\mathrm{km} / \\
\mathrm{sec})\end{array}$ & $\begin{array}{c}\text { Depth to } \\
\text { Top of Layer } \\
(\mathrm{km})\end{array}$ & $\begin{array}{c}\text { P-Wave } \\
\text { Velocity } \\
(\mathrm{km} / \\
\text { sec) }\end{array}$ & $\begin{array}{l}\text { Deptis to } \\
\text { Top of Layer } \\
(\mathrm{km})\end{array}$ & $\begin{array}{c}P \text {-Wave } \\
\text { Velocity } \\
(\mathrm{km} / \\
\mathrm{sec})\end{array}$ & $\begin{array}{l}\text { Depth to } \\
\text { Top of Layer } \\
(\mathrm{km})\end{array}$ \\
\hline 2.0 & 0.0 & 2.5 & 0.0 & 2.5 & 0.0 \\
\hline 3.1 & 1.0 & 5.1 & 0.4 & 4.5 & 1.5 \\
\hline 3.8 & 2.0 & 6.0 & 2.9 & 6.2 & 3.0 \\
\hline 4.6 & 3.0 & 7.1 & 14.0 & 7.0 & 12.5 \\
\hline 5.3 & 4.0 & 7.9 & 25.0 & 7.9 & 25.0 \\
\hline 5.8 & 4.8 & & & & \\
\hline 6.5 & 14.2 & & & & \\
\hline 7.3 & 15.4 & & & & \\
\hline 7.5 & 20.0 & & & & \\
\hline
\end{tabular}


The northeast trend events cluster in space and time. The first cluster consisted of the foreshocks and main shock. The seven foreshocks happened over a 22-min period before the main shock, included two events of $M_{L}>4.0$, and co-locate with the main shock. A few minutes later events scatter to the north and west of the main shock, just off the main northeast trend. A group of events occurred near the intersection of the northeast structure and the Superstition Hills fault $20 \mathrm{~min}$ to 1 hr after the main shock. This cluster remained active at a $M_{L}<2.5$ level until the second main shock. Next, about $2 \mathrm{hr}$ after the first main shock, a series of events occurred in the Brawley seismic zone, followed by aftershocks along the entire northeast trend.

The second main shock (1315:56.5, 24 November 1987 GMT) occurred 12 hrs after the first main shock at $33^{\circ} 0.9^{\prime} \mathrm{N}, 115^{\circ} 50.9^{\prime} \mathrm{W}$, and at a depth of only $2 \mathrm{~km}$. This location is at the intersection of the northeast trend defined by the aftershocks of the first main shock and the northwest trend defined by aftershocks of the second main shock. The aftershocks of the second main shock mostly lie west of the observed surface rupture on the Superstition Hills fault, in an area of low background seismic activity (Fig. 2). The aftershocks do not extend as far southeast on the Superstition Hills fault as the observed surface rupture. There is a group of aftershocks at the northwest end of the northwest trend. Excluding that group, the aftershocks extend only a few $\mathrm{km}$ northwest of the surface rupture. North of $32^{\circ}$ $58^{\prime}$ the aftershock distribution has a sharp western boundary. The sharp boundary aligns with, but does not overlap, the background seismicity trend that defines the Superstition Mountain fault (Fig. 2). This boundary becomes more diffuse south of $32^{\circ} 58^{\prime}$, where the aftershock activity drops dramatically. A few aftershocks are off the main northwest trend, north of the second main shock. Aftershock activity on the northeast trend stopped almost completely after the second main shock.

Figure 4 is a cross section perpendicular to the strike of the Superstition Hills fault. Note that the first main shock is deep (about $11 \mathrm{~km}$ ) and the second is shallow (about $2 \mathrm{~km}$ ). The maximum depth of aftershocks on both trends is the same (about $13 \mathrm{~km}$ ), but most of the events on the northeast trend are deep and most of the

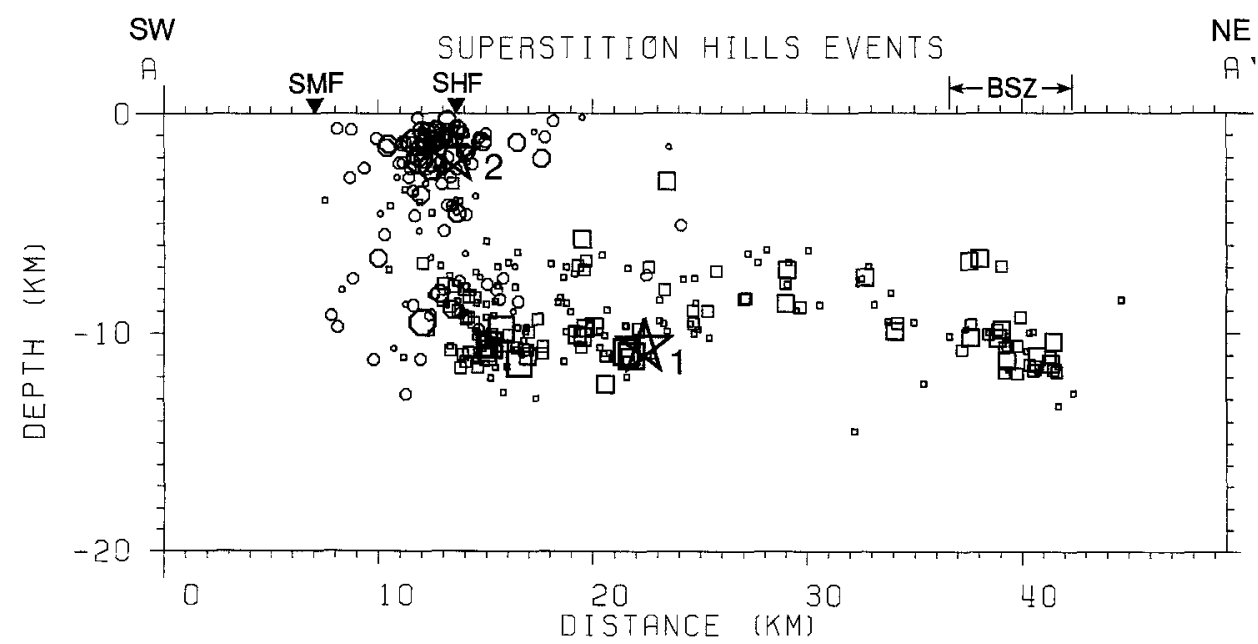

FIG. 4. Cross section perpendicular to the Superstition Hills fault. All events within $10 \mathrm{~km}$ of cross section are projected onto the plane of the figure. Intersections of cross section and faults are shown, with abbreviations as in Figure 1. Earthquake symbols as in Figure 3. Earthquake symbol size is proportional to earthquake magnitude. 
earthquakes on the northwest trend are shallow. The deepest (10 to $13 \mathrm{~km}$ ) northeast trend events are in two locations, west of the first main shock and in the Brawley seismic zone. Foci associated with the northwest trend, viewed along the azimuth of their trend, fill a volume between the Superstition Hills and Superstition Mountain faults, rather than defining a plane. Figure 5 is a cross section along the strike of the Superstition Hills fault. A large $\left(M_{L}=4.6\right)$, deep aftershock of the northwest trend occurs close to the join of the two trends.

The depth of the second main shock was tested in two ways. First, trial relocations at a range of fixed depths were made and travel-time residuals to nearby seismograph stations were compared. The minimum residuals occur for a shallow depth. Second, $P$-wave arrival times for nearby stations were swapped in and out of the phase file to ensure no erroneous pick was biasing the epicentral depth. The depth is insensitive to such swapping.

Focal mechanisms of $M_{L} \geqq 3.0$ events for which 15 or more reliable first motions could be obtained are displayed in Figure 6. A high-quality mechanism for the first main shock could not be calculated, because many of its first motions were obscured by an immediate foreshock. The mechanisms show mostly strike-slip faulting, with some having a component of normal or reverse slip. The foreshocks (numbers 2 and 3 on Fig. 6) and aftershocks of the first main shock (numbers 8, 9, 11, and 12) on the northeast trend have a nearly vertical fault plane parallel to the strike of the northeast trend. Because of observed left-lateral surface rupture and the hypocentral alignment, these events are most likely to be left lateral. Some aftershocks of the first main shock form a short northwest lineation within the northeast trend (numbers 4 to 7 and 13) and have similar mechanisms, but because of their position in the short northwest lineation, they may be right lateral on a northwest strike, representing activation of a northwest structure prior to the second main shock. The nodal-plane orientations of one event in the Brawley seismic zone (number 10) are different than the other aftershocks.

The mechanism of the second main shock (number 1) has a vertical northweststriking fault plane that agrees with the strike of the Superstition Hills fault. South of the main shock, the fault plane for right-lateral motion of the aftershocks (numbers $16,17,20$ to 25,27 to 29 ) tends to strike more nearly east-west than that

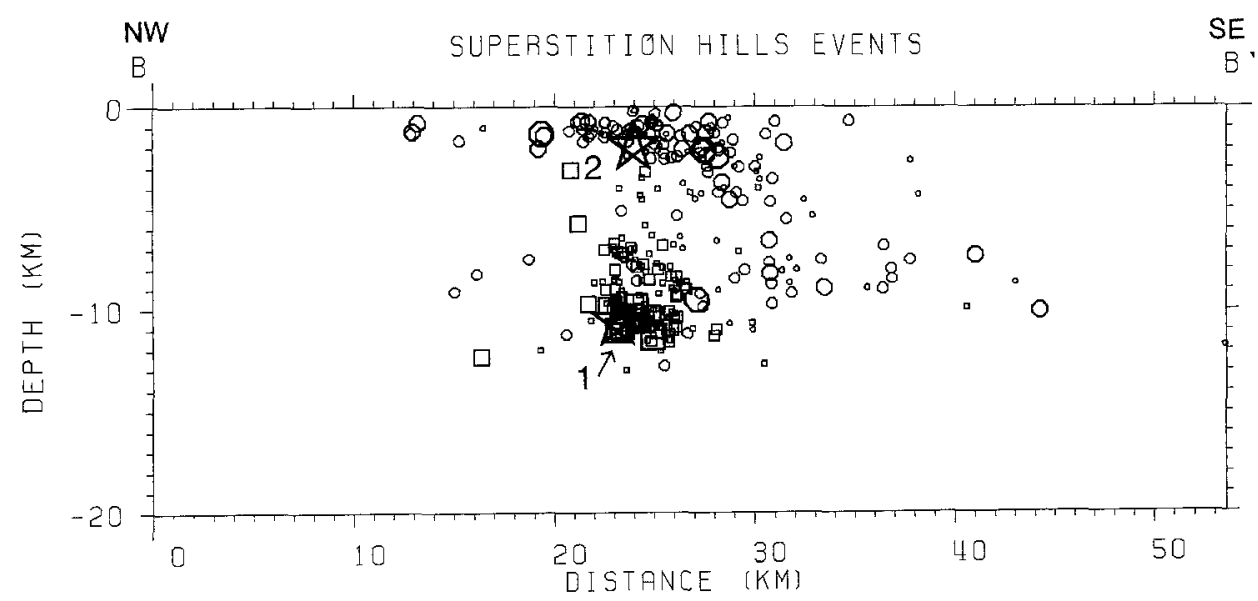

FIG. 5. Cross section parallel to the Superstition Hills fault. All events within $10 \mathrm{~km}$ of cross section are projected onto the plane of the figure. Earthquake symbols as in Figure 3. Earthquake symbol size is proportional to earthquake magnitude. 


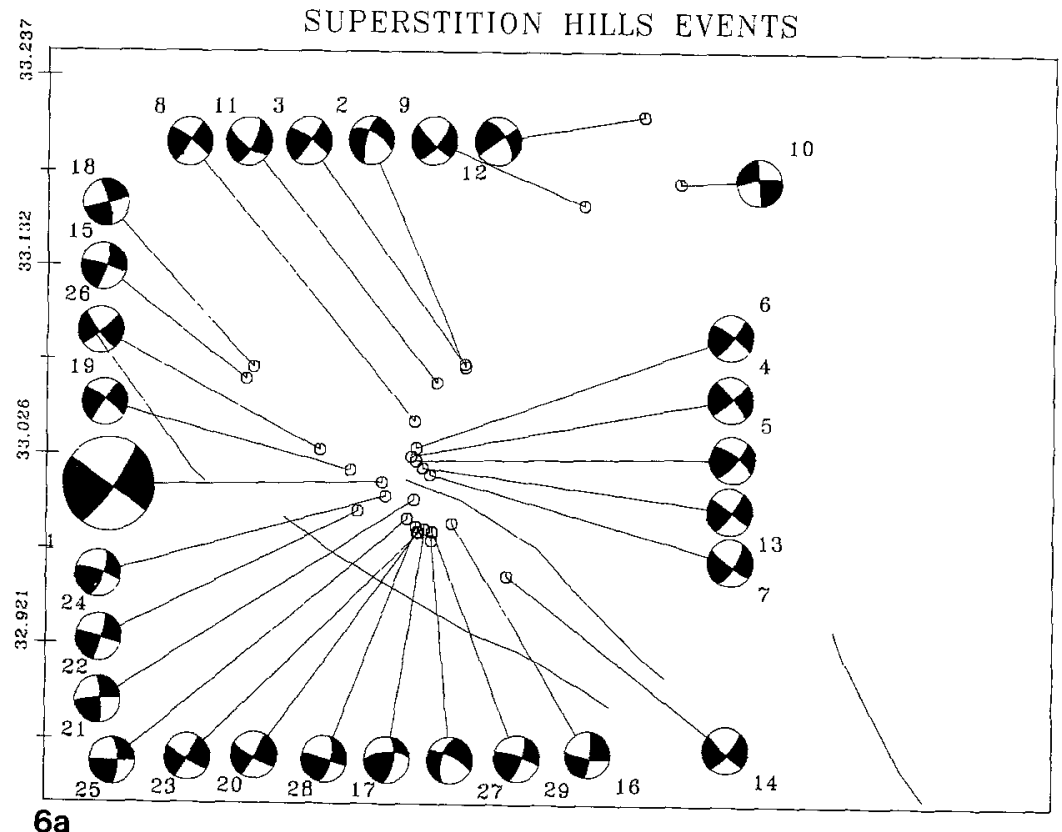

$6 a$
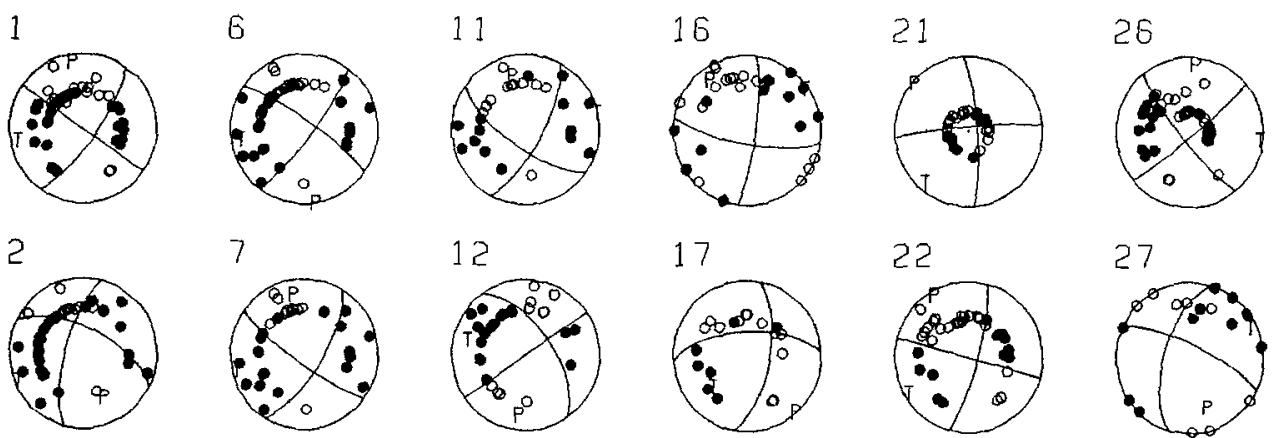

7

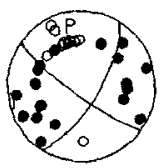

12

17

22

27
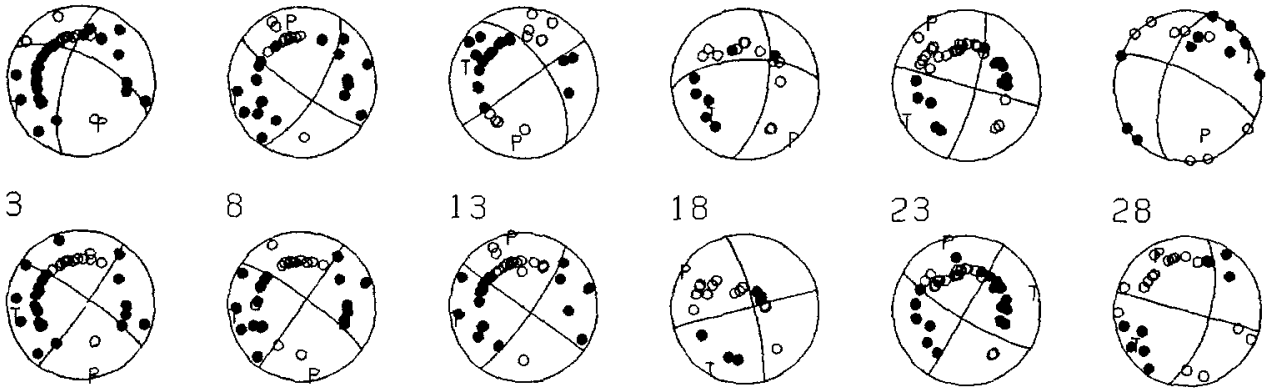

8

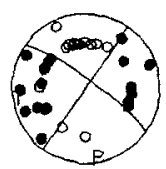

13

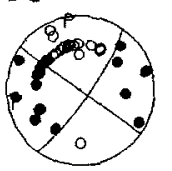

18

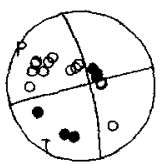

23

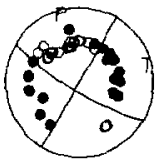

28

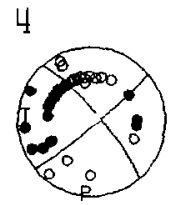

9

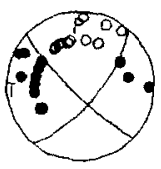

14

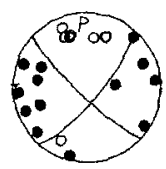

19

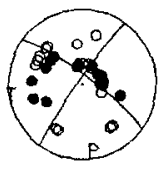

24
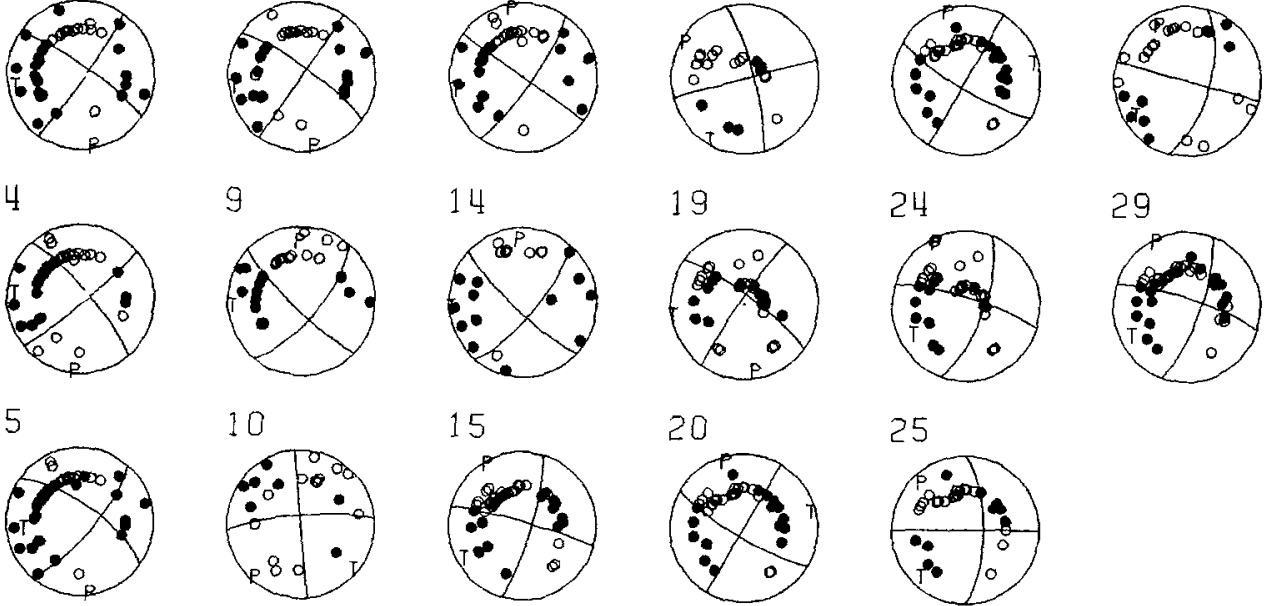

$6 b$

FIG. 6. (A) Focal mechanisms (lower hemisphere, compressional quadrants shaded) of selected $M_{L} \geqq$ 3.0 events. Second main shock shown by larger symbol. Numbers are for reference and do not indicate order of occurrence. (B) Lower hemisphere equal-area projections of $P$-wave first motions of events in Figure 6A. Filled circles, compressive first motions; open circles, dilatant first motions. 
of the main shock. North of the main shock, the aftershock mechanisms (numbers 19 and 26) closely match the main shock mechanism. Mechanisms of events in the northernmost group (numbers 15 and 18) differ. These events and the event in the Brawley seismic zone (number 10) did not occur on the principal conjugate fault system.

\section{INTERPRETATION}

The Imperial Valley lies astride the Salton trough, the sediment-filled landward extension of the actively spreading Gulf of California (Larson, 1972). Fuis et al. (1982) performed a large seismic refraction study in the Imperial Valley region. They combined seismic refraction, gravity, and well data to define two types of basement rocks. The first type, under the flanks of the Imperial Valley, are the prerifting continental crystalline plutonic and metamorphic rocks. These basement rocks are about $2-\mathrm{km}$ deep west of the Superstition Hills fault. The second type is metamorphosed sedimentary rocks under the central Imperial Valley at about a 5$\mathrm{km}$ depth under the southern Salton Sea. A steep basement gradient under the Superstition Hills fault separates the two basement types (Fuis et al., 1982). Reproduced in Figure 7 is a map of the structure and tectonics of the Imperial Valley area (from Fuis et al., 1982) showing the inferred extent of continental

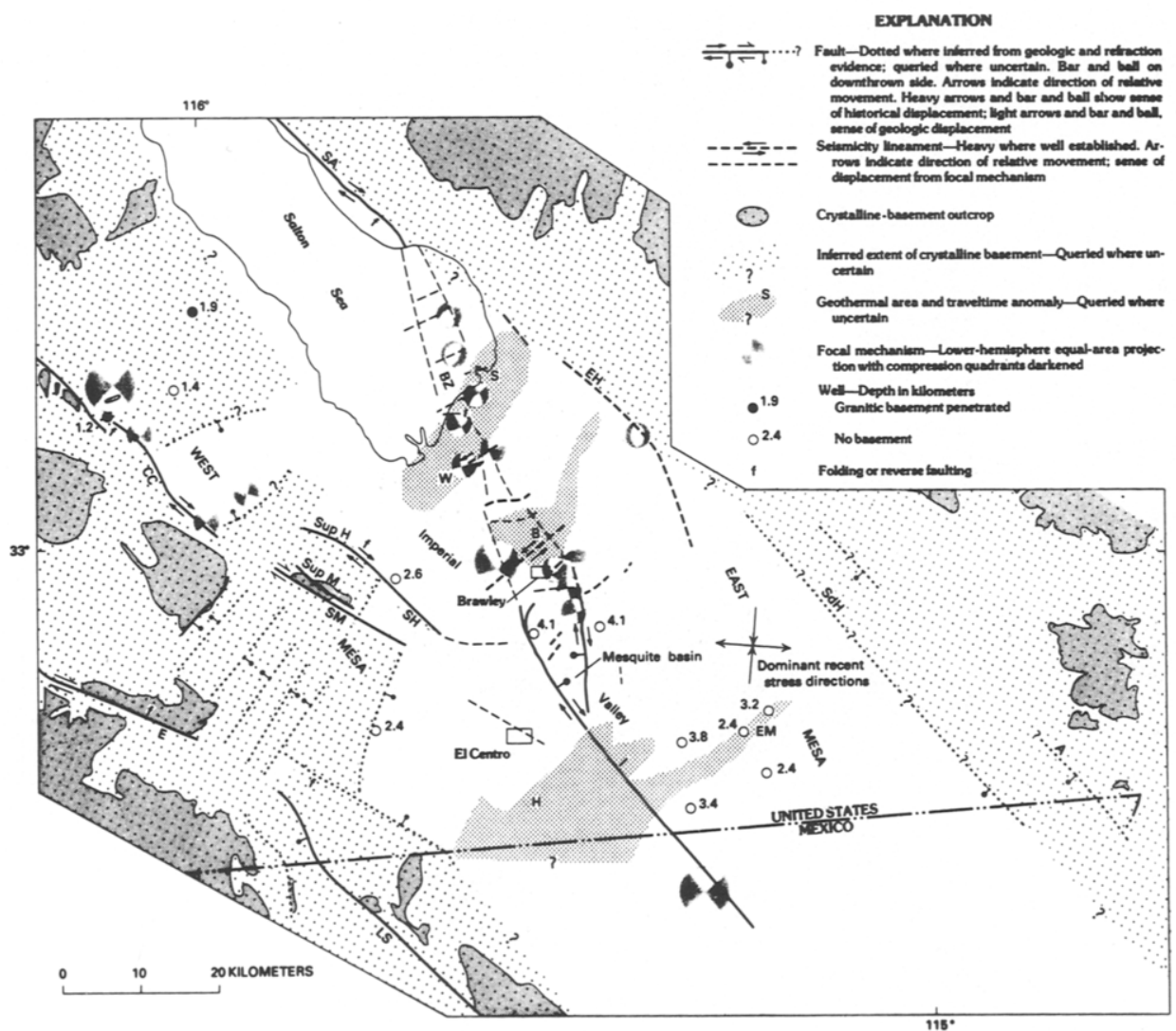

FIG. 7. Figure 24 of Fuis et al. (1982), showing tectonic and basement features of the Imperial Valley region as determined from refraction, gravity, and well data. Abbreviation: Sup M, Superstition Mountain. 
crystalline basement rocks. Note the complex distribution of crystalline basement rocks in the area of the Superstition Hills earthquakes.

Figure 8 shows the extent of the basement from Figure 7 superposed on an epicenter map. The first main shock and its foreshocks are located at a corner in the basement where the basement protrudes eastward into the Imperial Valley. Several aftershocks are distributed in the rest of the protrusion. The larger $\left(M_{L} \geqq\right.$ 3.5) aftershocks of the northeast trend lie no further northeast than the basement protrusion. The second main shock is at another, interior corner of the basement. The aftershocks on the Superstition Hills fault end both to the southeast and to the northwest where the basement ends. The group of aftershocks at the northwest end of the northwest trend cluster at a basement edge. There is an alignment of aftershocks along the basement edge at the south end of the northwest trend. The west edge of the northwest trend aligns with the fault bounding Superstition Mountain. We conclude that the larger earthquakes tend to occur within, or along the edge of, the crystalline basement rocks.

\section{Discussion}

The Superstition Hills earthquake sequence is unusual in two regards. First, a conjugate fault system was involved; the left-lateral northeast-striking structure and the right-lateral Superstition Hills fault. Second, the depth of the second main shock was shallow. That the first main shock on the northeast structure unlocked the Superstition Hills fault to produce the second main shock has a geometric appeal. The shallow initiation depth of the second main shock may be related to

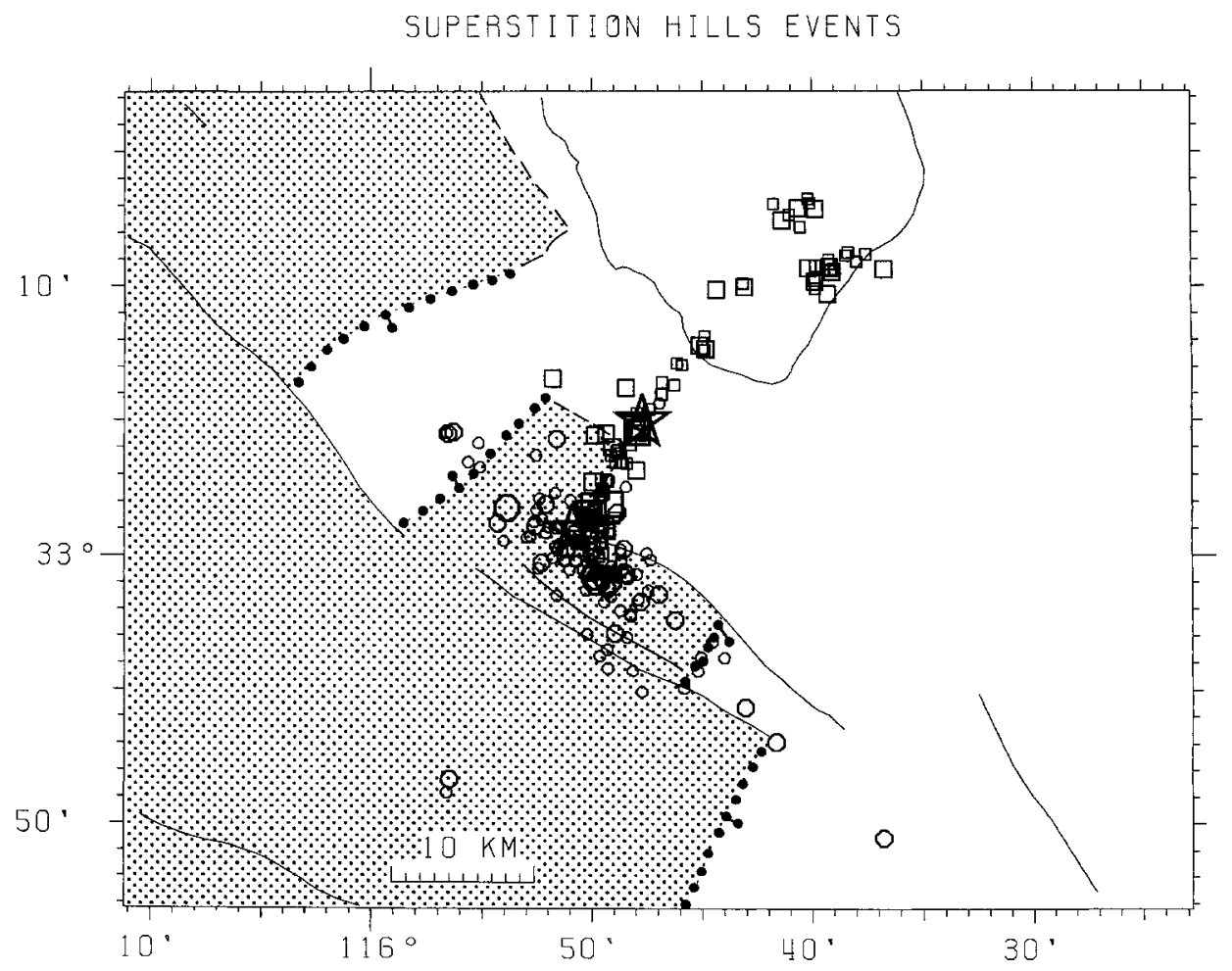

FIG. 8. Basement features from Figure 7 superposed on $M_{L} \geqq 2.0$ earthquake relocations from this study. Earthquake symbols as in Figure 3. Shading represents extent of crystalline basement. 
the unlocking mechanism. The strong motion records for the second main shock are complex (Huang et al., 1987; Porcella et al., 1987), showing multiple sources. The timing of the multiple sources is similar in strong-motion records written at Pasadena and El Centro, (P. Ho, personal comm.) to the northwest and southeast, respectively, suggesting that these multiple sources were located close together. It is possible that, while the fault rupture started at a shallow depth, much of the seismic energy could have been released from deeper on the fault.

As seen in Figure 8, the larger events of the northeast trend occur in the crystalline basement rocks defined by Fuis et al. (1982), but the northeast trend clearly continues beyond those rocks to the Brawley seismic zone. The northeast seismicity trend passes just north of the Westmorland and Salton geothermal areas (Figs. 1 and 7). These geothermal areas correlate with subtle anomalies in a traveltime contour map of Fuis et al. (1982). Also, the Salton Buttes volcanoes, at the southeast end of the Salton Sea, contain granitic xenoliths that may indicate the presence of crystalline plutonic rocks at depth (Robinson et al., 1976). Thus we speculate that the northeast trend continues from along the edge of well-defined continental crystalline basement rocks to either a metasedimentary basement feature or a bit of continent basement not resolved in the study of Fuis et al. (1982).

Figure 9 shows a north-south cross section of Caltech catalog locations of earthquakes in the Brawley seismic zone. The focal depths of events in the Brawley seismic zone shallow abruptly north of the junction of the northeast trend. This focal depth change may reflect basement structure. The northeast trend parallels a lineation within the Brawley seismic zone that developed during aftershocks of the 1979 Imperial Valley earthquake (Johnson and Hutton, 1982) and parallels the trend of the 1981 Westmorland sequence (Fig. 2). The Westmorland trend extended from the Brawley seismic zone to the Superstition Hills fault (Hutton and Johnson, 1981). This trend meets the Superstition Hills fault near the southern edge of the block of crystalline basement that lies between the Superstition Hills and Superstition Mountain faults. The southern edge of this block also parallels the Westmorland trend.

The current sequence illuminates the block of crystalline basement as a fault bounded structural unit. Many of the edges of the block are defined by aftershocks (Fig. 8). Aftershock lineations, such as shown in Figure 6 (numbers 4 to 7, 13),

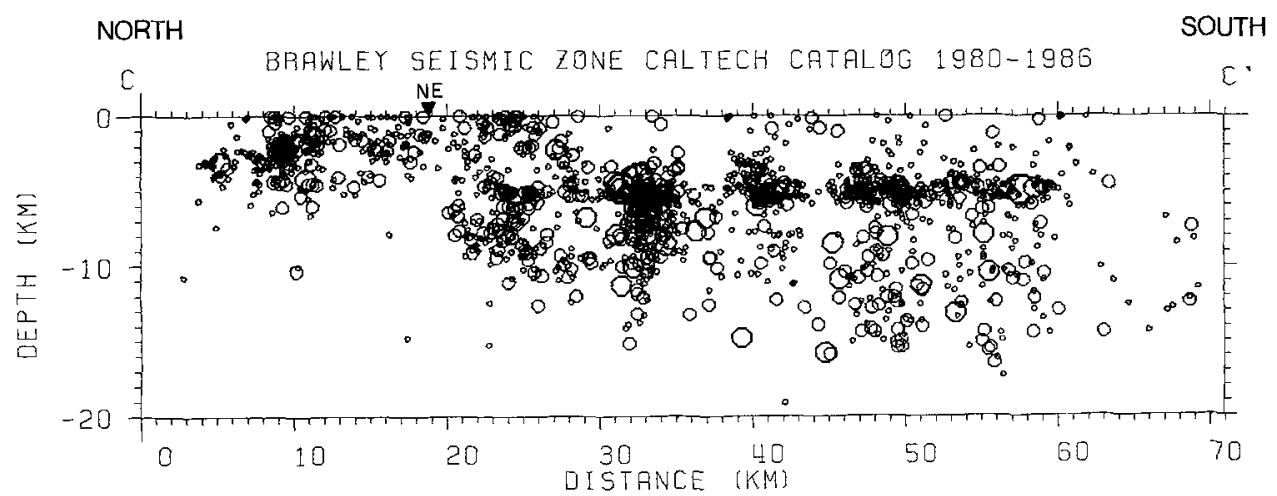

FIG. 9. Cross section parallel to the Brawley seismic zone (see Fig. 1) showing A and B quality earthquakes from the Caltech catalog from 1980 to 1986 . Events within $6 \mathrm{~km}$ of cross section are projected onto the plane of the figure. NE indicates the intersection of the cross section with the northeast trend of the Superstition Hills sequence. Earthquake symbol size is proportional to earthquake magnitude. 


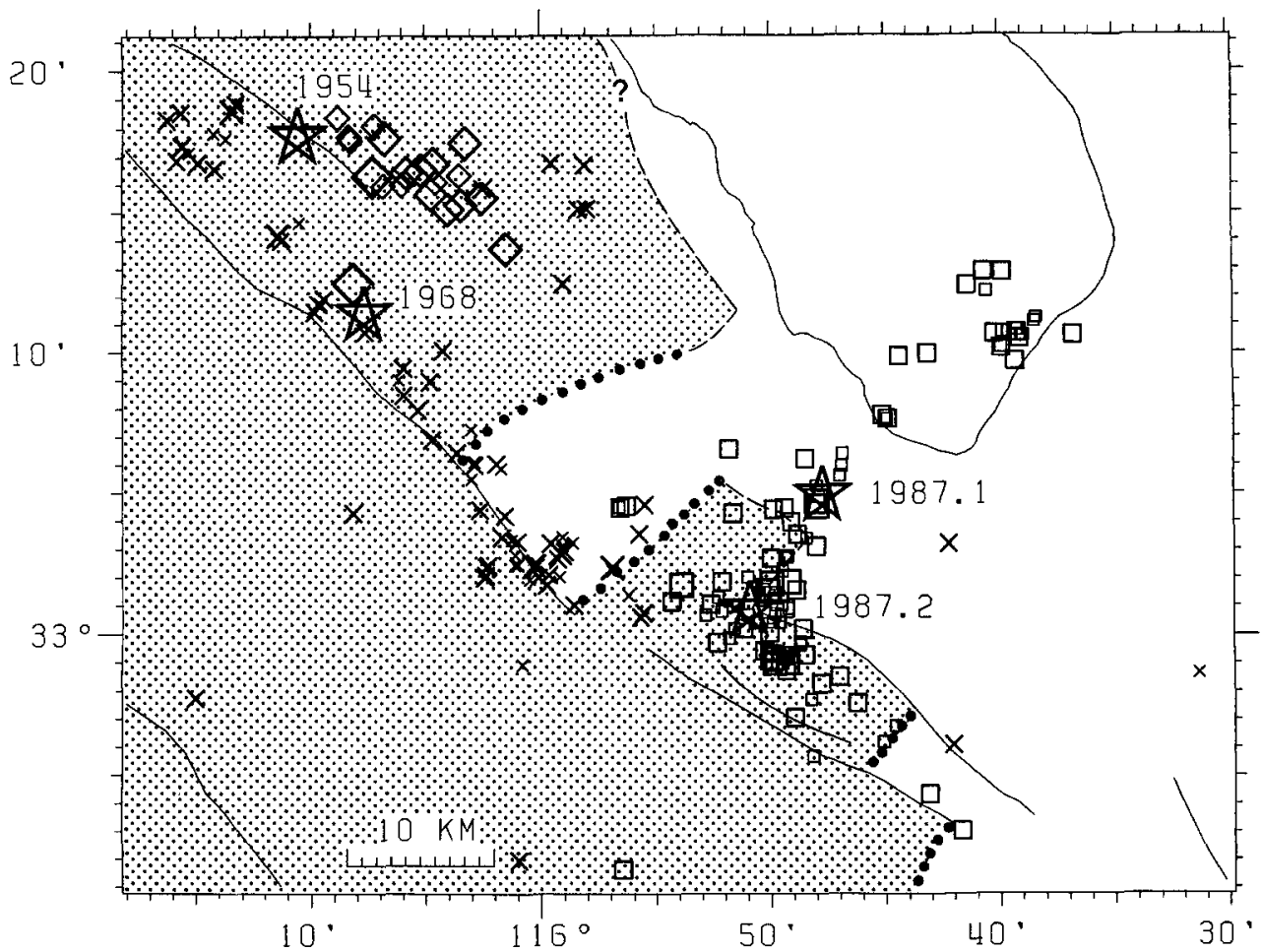

Fig. 10. Aftershock zones of the 1954, 1968, and 1987 earthquakes with basement features from Figure 7. Main shocks are indicated by stars, labeled with year of occurrence. Diamonds are $1954 M_{L} \geqq$ 3.9 aftershocks, $X_{s}$ are $1968 M_{L} \geqq 2.4$ aftershocks, and squares are $1987 M_{L} \geqq 2.4$ aftershocks. Shading represents extent of crystalline basement.

illustrate this. The block is bordered on the west by the fault bounded Superstition Mountains (Fig. 7). Aftershock activity does not extend under Superstition Mountain. Aftershocks of the 1954 Arroyo Salada earthquake, on the Clark strand of the San Jacinto fault zone, extend southeastward from the 1954 main shock (Sanders et al., 1986) but do not cross the basement embayment just north of the Superstition Hills fault (Fig. 10). Aftershocks of the 1968 Borrego Mountain earthquake (Hamilton, 1972) do not extend along the Coyote Creek fault past the southern edge of the basement embayment (Fig. 10). Therefore the extent of rupture, as defined by aftershock zones, is controlled by the basement structure in the western Imperial Valley.

\section{Conclusions}

The 24 November 1987 Superstition Hills earthquakes occurred on a conjugate fault system consisting of the northwest-striking right-lateral Superstition Hills fault and a previously unknown northeast-striking left-lateral structure defined by a hypocenter plane that reaches from the Superstition Hills fault to the Brawley seismic zone. The plane parallels other northeast-trending epicenter alignments. The earthquake sequence is made up of foreshocks, a main shock, and aftershocks on the northeast trend, followed by a main shock and aftershocks on the northwest trend. Master event relocations show the following. The northeast trend main shock and its foreshocks colocate at about 11-km depth. The aftershocks of the first main shock cluster in time and space, with some aftershocks occurring in the Brawley seismic zone. The second main shock was $12 \mathrm{hr}$ after the first main shock and 
initiated at shallow depth, at the join of the two trends. The northwest trend aftershocks do not coincide with observed surface rupture on the Superstition Hills fault and occupy a volume between the Superstition Hills and Superstition Mountain faults. In general, the northeast-trending events are deep and the northwesttrending events are shallow.

We compare the distribution of the earthquakes to the distribution of basement rocks defined by the refraction study of Fuis et al. (1982). The earthquake locations and extent of aftershocks appear to be controlled by the presence of crystalline basement rocks. This observation is useful in understanding future and historical earthquakes in the western Imperial Valley.

\section{ACKNOWLEDGMENTS}

We thank Iris Lutz and Bob Daniel of Unocal Geothermal Division for kindly supplying supplementary data from seismograph station KNB. Doug Given deployed the temporary strong-motion instrument at KNB. We also thank Caltech and USGS seismic data analysts Steve Bryant, Dean Dougherty, Riley Geary, Lisa Stack, and Kathy Watts for their hard work in timing the earthquakes. Chris Sanders, Doug Given, and Walter Arabasz provided thoughtful reviews. This work was supported by the U.S. Geological Survey under contract 14-08-0001-G1354. Contribution No. 4624, Division of Geological and Planetary Sciences, California Institute of Technology, Pasadena, California.

\section{REFERENCES}

Allen, C. R., P. St. Amand, C. F. Richter, and J. M. Nordquist (1965). Relationship between seismicity and geologic structure in the southern California region, Bull. Seism. Soc. Am. 55, 753-797.

Allen, C. R., M. Wyss, J. N. Brune, A. Grantz, and R. E. Wallace (1972). Displacements on the Imperial, Superstition Hills, and San Andreas faults triggered by the Borrego Mountain earthquake, in The Borrego Mountain Earthquake of April 9, 1968, U.S. Geol. Surv. Profess. Paper 787, 87-104.

Doser, D. I. and H. Kanamori (1986). Depth of seismicity in the Imperial Valley region (1977-1983) and its relationship to heat flow, crustal structure, and the October 15, 1979 earthquake, J. Geophys. Res. 91, 675-688.

Fuis, G. S. (1982). Displacement on the Superstition Hills fault triggered by the 1979 Imperial Valley earthquake, in The Imperial Valley, California, Earthquake of October 15, 1979, U.S. Geol. Surv. Profess. Paper 1254, 145-154.

Fuis, G. S., W. D. Mooney, J. H. Healey, G. A. McMechan, and W. J. Lutter. (1982). Crustal structure of the Imperial Valley region, in The Imperial Valley, California, Earthquake of October 15, 1979, U.S. Geol. Surv. Profess. Paper 1254, 25-50.

Given, R. D., R. Norris, L. M. Jones, L. K. Hutton, C. E. Johnson, and S. Hartzell (1986). The southern California network bulletin January through June, 1986, U.S. Geol. Surv., Open-File Rept. 86-598, $28 \mathrm{pp}$.

Hamilton, R. M. (1970). Time term analysis of explosion data from the vicinity of the Borrego Mountain, California, earthquake of 9 April 1988, Bull. Seism. Soc. Am. 60, 367-381.

Hamilton, R. M. (1972). Aftershocks of the Borrego Mountain earthquake from April 12 to June 12, 1968, in The Borrego Mountain Earthquake of April 9, 1986, U.S. Geol. Surv. Profess. Paper 787, 3154.

Huang, M. J., T. Q. Cao, C. E. Ventura, D. L. Parke, and A. F. Shakal (1987). CSMIP strong motion records from the Superstition Hills, Imperial county, California, earthquakes of 23 and 24 November 1987, Report No. OSMS 87-06, California Strong Motion Instrumentation Program, 42 pp.

Hutton, L. K. and C. E. Johnson (1981). Preliminary study of the Westmorland, California, earthquake swarm (abstract), EOS 62, 957.

Johnson, C. E. (1979). CEDAR-An approach to the computer automation of short-period local seismic networks; seismotectonics of the Imperial Valley of southern California, Ph. D. thesis, Pasadena, California Institute of Technology, $343 \mathrm{pp}$.

Johnson, C. E. and L. K. Hutton (1982). Aftershocks and preearthquake seismicity, in The Imperial Valley, California, Earthquake of Octaber 15, 1979, U.S. Geol. Surv. Profess. Paper 1254, 59-76.

Klein, F. W. (1985). User's guide to HYPOINVERSE, a program for VAX and PC350 computers to solve for earthquake locations, U.S. Geol. Surv., Open-File Rept. 85-515, 24 pp.

Larson, R. L. (1972). Bathymetry, magnetic anomalies, and plate tectonic history of the mouth of the Gulf of California, Geol. Soc. Am. Bull. 83, 3345-3360. 
Norris, R., C. E. Johnson, L. M. Jones, and L. K. Hutton (1986). The southern California network bulletin, U.S. Geol. Surv., Open-File Rept. 86-96, 31 pp.

Porcella, R., E. Etheredge, R. Maley, and J. Switzer (1987). Strong-motion data from the Superstition Hills earthquakes of 0154 and 1315 (GMT), November 24, 1987, U.S. Geol. Surv., Open-File Rept. $87-672,56 \mathrm{pp}$.

Reasenberg, P. and D. Oppenheimer (1985). FPFIT, FPPLOT, and FPPAGE: computer programs for calculating and displaying earthquake fault-plane solutions, U.S. Geol. Surv., Open-File Rept. 85$739,46 \mathrm{pp}$.

Robinson, P. T., W. A. Elders, and L. J. P. Muffler (1976). Quaternary volcanism in the Salton Sea geothermal field, Imperial Valley, California, Geol. Soc. Am. Bull. 87, 347-360.

Sanders, C., H. Magistrale, and H. Kanamori (1986). Rupture patterns and preshocks of large earthquakes in the southern San Jacinto fault zone, Bull. Seism. Soc. Am. 76, 1187-1206.

Sharp, R. V. (1972). Tectonic setting of the Salton trough, in The Borrego Mountain Earthquake of April 9, 1968, U.S. Geol. Surv. Profess. Paper 787, 3-15.

Sharp, R. V. (1982). Tectonic setting of the Imperial Valley region, in The Imperial Valley, California, Earthquake of October 15, 1979, U.S. Geol. Surv. Profess. Paper 1254, 5-14.

Sharp, R. V., M. J. Rymer, and J. J. Lienkaemper (1986). Surface displacement on the Imperial and Superstition Hills faults triggered by the Westmorland, California, earthquake of 26 April 1981, Bull. Seism. Soc. Am. 76, 949965.

California Institute of Technology

SEISMOLOGICAL LABORATORY, 252-21

Pasadena, California 91125

(H.M., H.K.)

Manuscript received 11 April 1988
U. S. Geological Survey

525 South Wilson Avenue

Pasadena, California 91106

(L.J.) 